\title{
Bedugul Portrait: An Ethnoecological Study of the Relationship Between Man and the Environment
}

\author{
Wawan Sujarwo \\ Bali Botanical Gardens, Indonesian Institute of Sciences (LIPI), Tabanan, Indonesia
}

Artikel Masuk : 5 November 2018

Artikel Diterima : 15 Maret 2019

Tersedia Online : 30 April 2019

\begin{abstract}
Bedugul is situated in the highlands of Bali, combining panoramic views of hills, forests, and lakes. Today, Bedugul has transformed from a remote area into a favorite tourist destination. Also, Bali has become one of the world's leading tourist destinations, and this represents a suited model to study the influence of recent modernization, the tourist industry, population increase, and agricultural practices on traditional ecological knowledge (TEK). At the same time, few scientific references discuss Bedugul in term of TEK. Therefore, this study aims to present the latest portrait of Bedugul community in the millennial era and its relationship with the surrounding environments. A total of 20 Bedugul locals were interviewed. The selection of respondents was purposive, representing various Hindus and Moslem communities, with variations in age range (25-60 years old), gender, and occupation. The data were then analyzed through a qualitative descriptive approach with in-depth discussion. The results of the study showed that the Bedugul landscape has a strong cultural and ecological relationship with its communities, i.e., Hindus and Moslems. People activities in the natural areas of Bedugul, i.e., Batukahu Nature Reserve, are still in the normal stage. Most of Bedugul communities strongly depend on agricultural and tourism sectors. Land-use changes (human settlements, tourism facilities, and agricultural land) and the increasing population growth have resulted in the carrying capacity of Bedugul area becoming very vulnerable, and one of them is the emergence of pest species. The negative impacts of agricultural and tourism activities have been identified, some of which were using inorganic pesticides in high-doses, traffic congestion, and Lake Beratan water pollution due to restaurant waste and speed boat oil spills. This may result in the decline of local values within the Bedugul communities. This study concluded that erosion of traditional ecological knowledge, including ethnobotanical knowledge, is at risk of increasing.
\end{abstract}

Keywords: agriculture; Bali; Beratan Lake; traditional ecological knowledge; tourism

\section{Introduction}

During the Dutch colonial era, before Indonesia gained its independence in 1945, the Government of the East Indies was instrumental in arranging the area of Bali. In general, almost all the people who live and inhabit Bedugul currently come from East Bali (Karangasem Regency). At that time, the forest area in East Bali was degraded by the impact of Mount Agung eruptions, and the extraction of natural resources conducted by the Dutch colonial government. It was then that the Dutch took the initiative to restore the 


\section{Bedugul Portrait: An Ethnoecological Study of the Relationship Between Man and the Environment}

function of the existing forest in East Bali by moving some of the population from East Bali and allowed them to use forest land in the Bedugul area instead of their former homeland in the East.

Bedugul itself is known as "Pura Subak/Hindus Temple," and is not the name of a place that is administratively recognized by the Government of Indonesia. Pura Subak "Bedugul" is located on the south side of Lake Beratan (Planck \& Sutawan, 1983). The location around Pura Subak is stunning, combining panoramic views of hills and lakes, making it a popular tourist destination. Thus, many people and tourists (domestic and foreign) know this area as Bedugul.

Today, Bedugul has transformed from a remote location in the highlands of Bali Island to a favorite tourist destination for both domestic and foreign tourists, and Ulun Danu Beratan Temple has been a cultural icon for Bali and Indonesia. So far, few scientific references discuss Bedugul in term of traditional ecological knowledge (TEK). At the same time, Bali has become one of the world's leading tourist destinations (Central Board of Statistics of Bali Province, 2017), and this represents a particularly well-suited model to study the influence of recent modernization, the tourist industry, population increase, and agricultural practices on traditional ecological knowledge. Therefore, this study aims to present the latest portrait of Bedugul community in the millennial era and its relationship to the surrounding environment.

\section{Methods}

\section{Study Area}

The study was conducted in Bedugul, which is mainly situated in Candikuning Village, Tabanan Regency, Bali. The Bedugul area covers several villages, including Batunya, Candikuning, and Pancasari (Central Board of Statistics of Bali Province, 2017). Located in the highlands of Bali Island, Bedugul is famous for its cold air, fog, fresh produce, Bali Botanical Gardens, Beratan Lake and its Ulun Danu Temple, and many villas and homestays (Purnama \& Ardyanti, 2017). The study area can be seen in Figure 1.

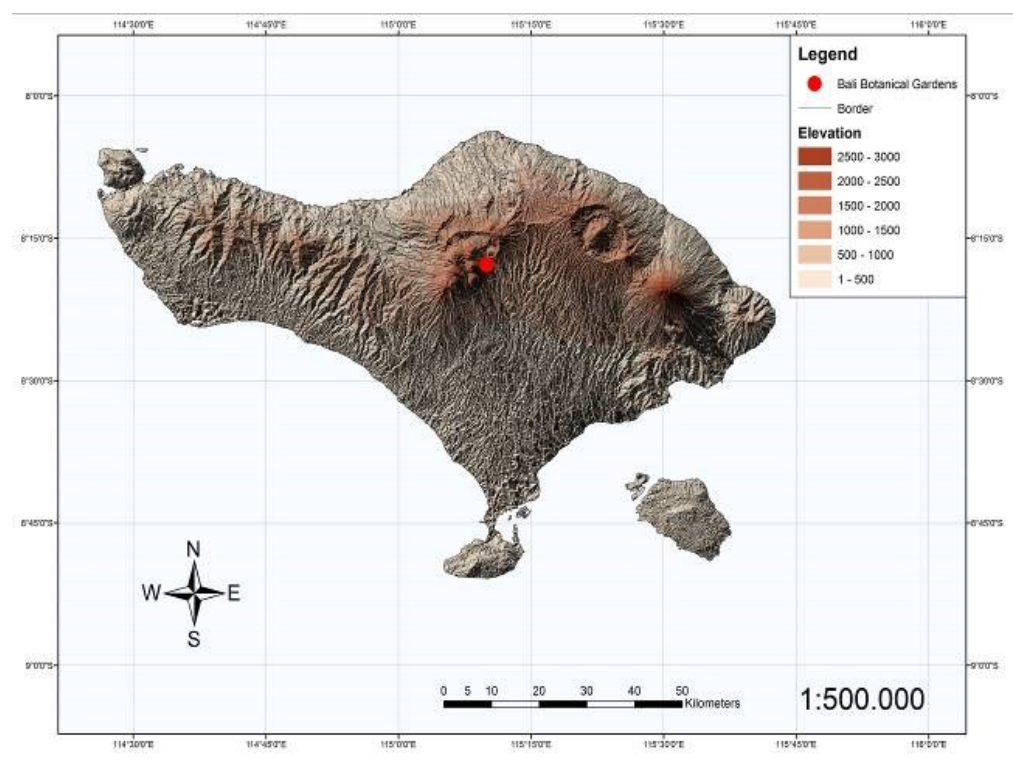

Source: Author, 2018

Figure 1. Study Area (in a circle) 


\section{Data Collection and Analysis}

The data were obtained by interviewing 20 respondents who are all Bedugul locals, representing various Hindus and Moslems communities, variations in age range (25-60 years old), gender, and occupation. The ethnoecological approach focusses on how different groups of people (community) living in a location understand the ecosystem around them, and their relationship with the surrounding environments (Inglis, 1993). The obtained data were analyzed using qualitative descriptive methods with in-depth discussions (Kvale, 1996).

\section{Result and Discussion}

\section{Bedugul Horticultural Products}

From an ecological perspective, the Bedugul area is unique, is located at an altitude of $1250-1400 \mathrm{~m}$ above the sea level (asl), and surrounded by the hills of Tapak, Pohen, and Penggelengan respectively. Rainfall in Bedugul is quite high, reaching more than 3,000 $\mathrm{mm}$ per year, making it suitable for agricultural and plantation areas (Central Board of Statistics of Bali Province, 2017). Bedugul communities rely heavily on the horticulture sector. The main horticultural commodities include leek (Allium ampeloprasum L.) on Figure 2, broccoli (Brassica oleracea var italic), bell pepper (Capsicum annuum L.), potato (Solanum tuberosum L.), chili (Capsicum annuum L.), strawberry (Fragaria $x$ ananassa (Duchesne ex Weston) Duchesne ex Rozier), and spice types, such as mint (Mentha arvensis L.), tarragon (Artemisia dracunculus L.), parsley (Petroselinum crispum (Mill.) Fuss), and rosemary (Rosmarinus officinalis L). Horticultural products are distributed in two ways; firstly, good quality products are taken directly by the supplier and sold to hotels in Bali, and secondly, medium quality products are offered to suppliers to be distributed to all traditional markets in Bali and beyond, so all crop production can be sold. If Indonesia's economic growth trend continues to rise, and the tourism sector remains stable, then the market potential will remain high to absorb all horticultural products produced in Bali. In addition, the actors of the supply chain of horticultural products from Bedugul are mostly Bedugul locals. In other words, besides being farmers, many locals are also suppliers of vegetables and fruit, which are contributing to the developing agrotourism sector.

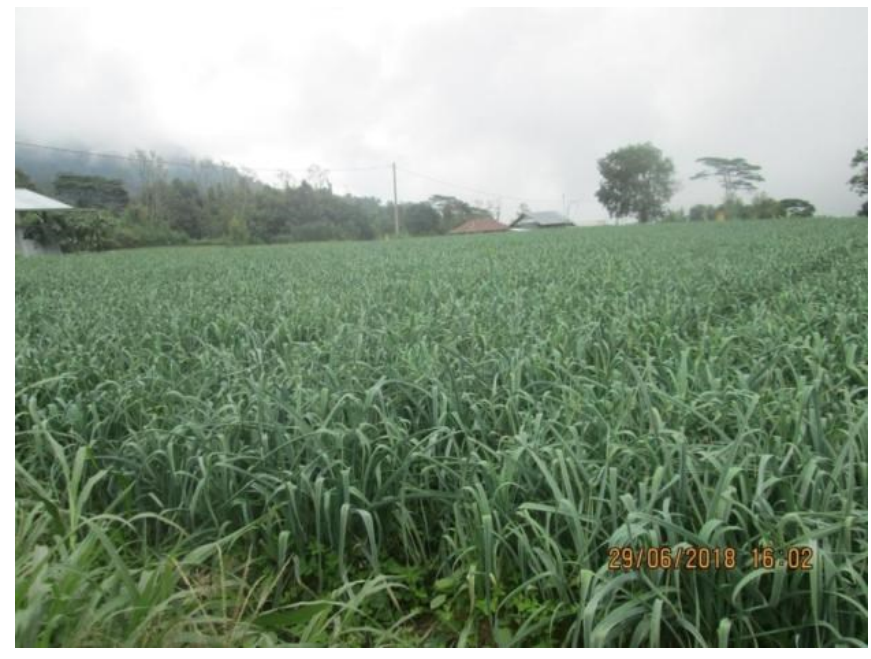

Figure 2. Leek (Allium ampeloprasum L.)

(One of the main horticultural products in Bedugul and many Bedugul farmers rely heavily on this product) 


\section{Bedugul Portrait: An Ethnoecological Study of the Relationship Between Man and the Environment}

In the process of cultivating horticultural crops (Figure 3), it cannot be separated from the fertilization and pest control. Until now, almost all Bedugul farmers use inorganic fertilizers in high doses. Consumers fear that products from this area are not organic and thus can endanger their health. In addition to the overuse of fertilizing, pest management also uses the high doses of inorganic chemicals. Environmental changes in Bedugul area and the increasing population growth have resulted in the carrying capacity of the catchment area becoming very vulnerable, and one of them is the emergence of pest species. Pest control becomes an obligation for farmers to keep their crops successful, although it can increase the negative environmental impacts that may arise in the future (Ratnasari, Siaka, \& Suastuti, 2013).

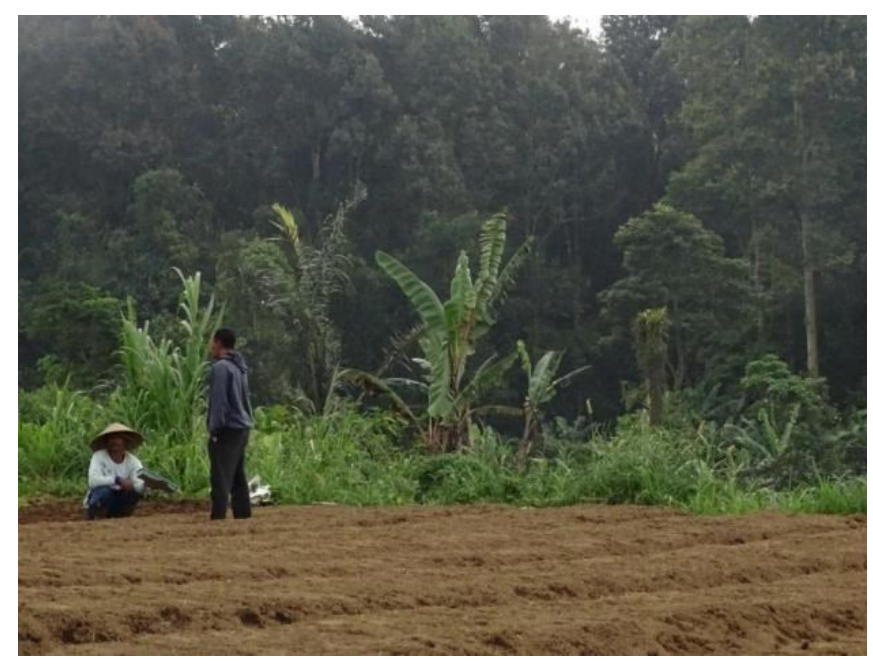

Figure 3. Horticultural Lands

(Two farmers talked each other about their experience on how to keep their crops successful)

\section{Endorheic Basin and Beratan Lake}

In addition to being in the highlands, the Bedugul area is also located in the ThreeLake area (Beratan, Buyan, and Tamblingan). Scientifically, many experts refer to the Bedugul area as an Endorheic Basin, which is considered to be an ancient volcano erupting to form a caldera and several lakes therein (Atmaja, Budiastuti, Setyono, \& Sunarto, 2018). One of the most famous lakes and icons of Bali is Beratan Lake. Ulun Danu Temple, which is on the edge of Beratan Lake, is one of the object images found on the currency of five thousand rupiah note. The Bedugul community has a strong relationship to Beratan Lake. Culturally, Beratan Lake (Figure 4) is sanctified by Balinese Hindus. People use lake water in every Hindus religious ceremony, thus building a place called "Beji," used to purify religious symbols every time there is "piodalan" (religious ceremony) in each ThreeTemples of Kayangan (Puseh, Desa, and Dalam) (Rema, 2013). In addition to religious ceremonies, lake water is also consumed for the daily needs of the people of Bedugul, i.e., drinking water. Another notable function is the "subak," the Balinese agricultural irrigation system. The lake water is flowed to the lower side of Beratan Lake to irrigate agricultural land, especially in the dry season. The water regulation is done following the customary Balinese rules and is governed by a "Subak Kelian," a person who is responsible for and understands the water cycle system (Suradisastra, Sejati, Supriatna, \& Hidayat, 2002). 


\section{Philosophical Symbols of Bedugul Community and Forest Area of Batukahu Nature Reserve (Pohen and Tapak Hills)}

Besides being in an endorheic basin, the Bedugul area also has a topography surrounded by green hills. Tapak and Pohen Hills are a stretch of the Batukahu Nature Reserve (Figure 5) which is one of the greenest spots on the island of Bali. Both hills have strong cultural and ecological relationships with the Bedugul communities, both Hinduism and Islam (Sumantera, 2004). This can be seen from the evidence of places of worship, such as Ulun Danu Temple in Beratan Lake, Teratai Bang Temple at the foot of Tapak Hill, Tomb of Islamic Figure (Sunan) at the top of Tapak Hill, and Pengungangan Temple at the foot of Pohen Hill. The Bedugul community place areas of worship in some places they consider to be sacred (Candrawan, 2015). Additionally, regarding cultural and ecological relationships, Tapak and Pohen Hills are also sources of springs and an ecological buffer zone of the hydrological cycle. Unfortunately, sometimes these areas are prone to landslides due to the high intensity of rainfall.

Furthermore, a small proportion of the Bedugul people depend on the forests on both hills, for firewood to use as fuel to boil peanuts and corn, passion fruit (Passiflora edulis), Asplenium nidus leaves as an inorganic flower ornament sold at Pasar Kandang, an art and product market which is quite famous in the Bedugul area. People also look for hummus as a planting medium, because some residents in Bedugul also sell ornamental plants, such as orchids, aroids, fruit crops, and other flower plants (Nugroho, Undaharta, \& Siregar, 2008). Although the forest areas of Pohen and Tapak Hills are Nature Reserve areas, which means any activities from the surrounding communities, are not allowed, the current situation is not considered to be disturbing or causing damage to the forest area. People activities that enter the area of Batukahu Nature Reserve are still in the normal stage, which can be seen from the composition, density, and canopy of vegetation growing in the Nature Reserve.

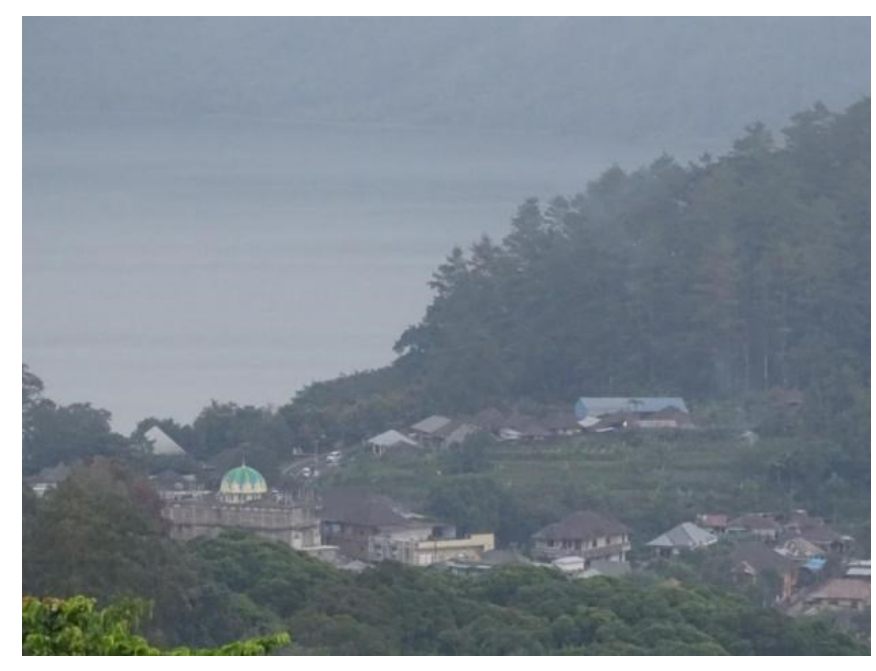

\section{Figure 4. Beratan Lake \\ (The third largest lake in Bali island where the majestic Ulun Danu Temple is located)}

\section{Religion: Islam and Hinduism}

The Bedugul name itself comes from the word "Bedug" and "Kukul." Both words are a blend of Islamic and Hinduism culture in the village of Candikuning, which until now have been able to live side by side in the absence of religious conflict. Both communities developed the area of what was once a Dry Highland Forest. Even the first-generation community of Islam Candikuning named their self with the clan of BICK (Bali Islam 


\section{Bedugul Portrait: An Ethnoecological Study of the Relationship Between Man and the Environment}

Candikuning) as a sign that they are the people of Candikuning Village. The socio-cultural conditions of the Bedugul people, both Hindus, and Moslems, still hold firm religious traditions, as evidenced by the increase of mosque constructions, the restoration of Hindus temples (Figure 6), and the many residents who attend these places of worship. For decades, Bedugul has become one of the central development points of Islam in Bali, marked by the establishment of several Islamic boarding schools (Figure 7), Islamic schools, and many mosque buildings (Vickers, 1987). Two different religious majority communities inhabit population growth in Bedugul; namely Islam and Hinduism. The Islamic community mainly shows a significant trend. This is inseparable from the philosophical thinking of Islam that having many children will be the agent of spreading their religion for the sustainability of Islam into the future. Thus, many of the previous generations of Bedugul Moslems allegedly did not follow National Family Planning Programs or use contraceptive tools. Besides, the process of acculturation of marriage within the other community, especially from Java and Lombok, has also further increased the growth of the Islamic community in Bedugul.

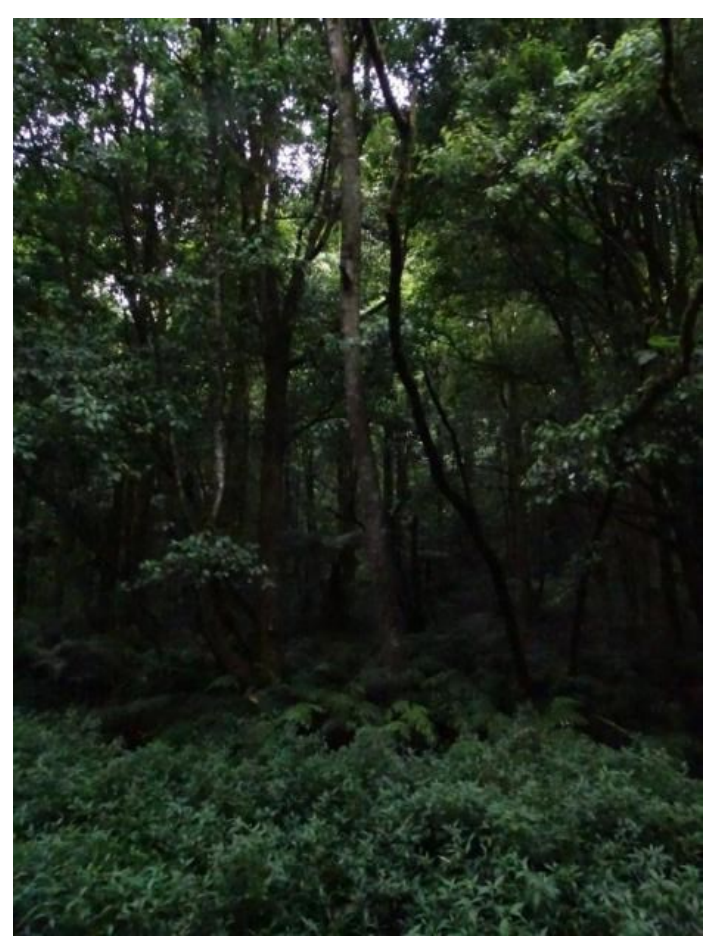

\section{Figure 5. One of the Spots Inside the Batukahu Nature Reserve (The forest is still in good condition, and people penetration to the area is in the normal stage)}

Along with increasing economic and tourism growth, many outsider communities living in Candikuning Village, including employees of Bali Botanical Gardens are generally from outside Bali. On the contrary, in Hinduism community, especially amongst the younger generation, these locals choose to work outside Bedugul or even abroad as crew members of the cruise ship as one example. This has led to population migration and cultural erosion within Hindu communities.

\section{Canang Sari: Balinese Hindu Ceremony Means}

Various religious ceremonies, especially in Hinduism, are numerous and varied. The use of the daily ceremony for Hindus is commonly called "Canang Sari," and varies greatly in composition and requires special skills to make it. The need for Canang Sari for Balinese 
Hindus is prevalent. Balinese Hindus engage in Canang Sari three times a day, and it is placed in many parts of homes, furniture, and vehicles.

In today's modern era, very rarely citizens, especially the younger generation, understand the composition and plant material used to make Canang Sari, so many Bedugul people buy ready-made Canang Sari in traditional markets (Atmadja, Ariyani, \& Atmadja, 2016). This occurs due to the busy lives of people within the community, and it is feared that the knowledge of how to make these offerings and sustainability of plant species used for Bali Hindus ceremonies will be lost. On the other hand, there are still a small number of Bedugul people who care about the preservation of ceremonial plants, by planting most of the plants used in ceremonies around their homes and yards. This group usually works as handymen (makers of Balinese Hindu ceremonial facilities), although there are also some common people who plant ceremonial plants and know how to make and prepare Canang Sari instead of buying them.

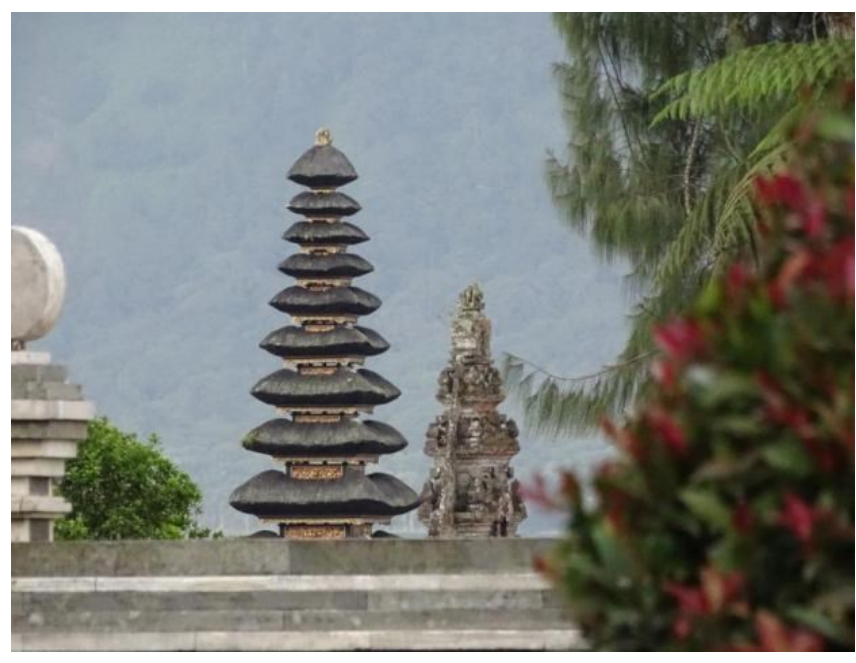

Figure 6. Balinese Hindu Temple (A good example on Balinese Hindu Temple looks like)

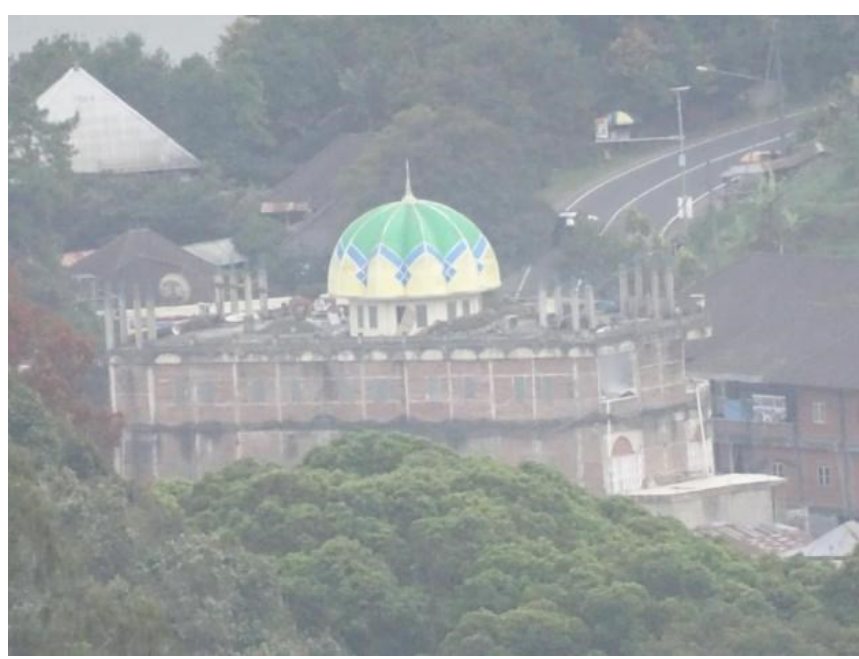

Figure 7. Islamic Boarding School (One of the Arabic language learning centers in Bali island) 


\section{Bedugul Portrait: An Ethnoecological Study of the Relationship Between Man and the Environment}

\section{Usada Taru Premana}

One of Bali's most interesting local knowledge is "Usada Taru Premana," which is a book of traditional Balinese medicine, using the parts of plants (Sujarwo, Keim, Savo, Guarrera, \& Caneva, 2015). This local knowledge should be preserved to reduce the dependence on chemical-based drugs, and the need to import medicine from other countries. However, traditional plant-based medicine has begun to fade within Bedugul community; the penetration of modernity resulted in the community chooses something more practical (Sujarwo, Arinasa, Salomone, Caneva, \& Fattorini, 2014). The use of traditional medicine requires a longer healing time than modern medicine, so people prefer to use the nearest doctor or health center for quicker resolution of their health issues.

Bedugul is a high-altitude area with cool temperatures, mist, and high intensity of rainfall. These conditions have made Bedugul locals more susceptible to colds, coughs, shortness of breath, and rheumatism (Oktavia, Darma, \& Sujarwo, 2017). Some of these diseases are very closely related to Bedugul's natural conditions. Living in areas with low temperatures and relatively low air pressure makes the health of Bedugul residents vulnerable to health issues, and thus should be balanced with nutritious food intake, and regular exercise to keep the vitality of the body.

\section{Positive and Negative Impacts of Tourism Sector}

In addition to the agricultural sector, Bedugul people also receive income from tourism and supporting activities. The tourism sector has opened new jobs for locals, ranging from selling souvenirs, food and beverage, lodging, photography, and tourist attractions (Figure 8) such as speed boat and banana boat tours on Beratan Lake. Positive impacts, both directly and indirectly, have been realized by the Bedugul communities. Now many parents have been able to send their children to study at universities, and they can afford more luxurious homes and cars. In other words, the lives of Bedugul people is developing economically, moving them closer to a middle-class status with more expendable income. By contrast, tourism can also have negative impacts and thus needs to find a solution as soon as possible (Cukier-Snow \& Wall, 1993). One of the most common problems is traffic congestion on weekends, school holidays, and public holidays. Alongside this, lake water pollution, due to tourism supporting activities, such as restaurant waste, speed boat fuel spills, and inorganic waste (plastics), has become a serious problem for water health and biota of Beratan Lake. Sedimentation of Beratan Lake has also been identified to be a future problem if there is no serious management from the stakeholders. It could cause serious devastation through siltation of the lake if preventative measures are not taken.

\section{Flash Flood}

High rainfall is sometimes a serious problem for the people of Bedugul. For example, in 2017, landslides and flash floods (Figure 9) from upstream of Tapak Hill hit the Bali Botanical Gardens, destroying bridges, roads, and some existing infrastructure in the garden. Besides, there are still piles of rocks, mud, and wood debris that cover some location points in the gardens as a result of this natural disaster. This happened because the structure of the forest soil was saturated with so much rainwater, and the vegetation was almost close to a climax, making the mechanical load on the ground double. Since Bali Botanical Garden is located right at the foot of Tapak Hill, the impacts of damage caused by landslides and flash floods were significant. The damage did not only occur within the area of Bali Botanical Gardens but in almost all Bedugul areas with bridges and some houses being destroyed, along with river erosion. Bedugul community believes that a $30-$ year wet-season cycle was indeed happening at the time, and that was supported by climatology and hydrological experts who agreed that the period 2007-2037 is a wet season 
period (As-syakur, 2007). Landslides and flash floods also occurred previously in 1967, which was a period that was also believed to be a wet season.

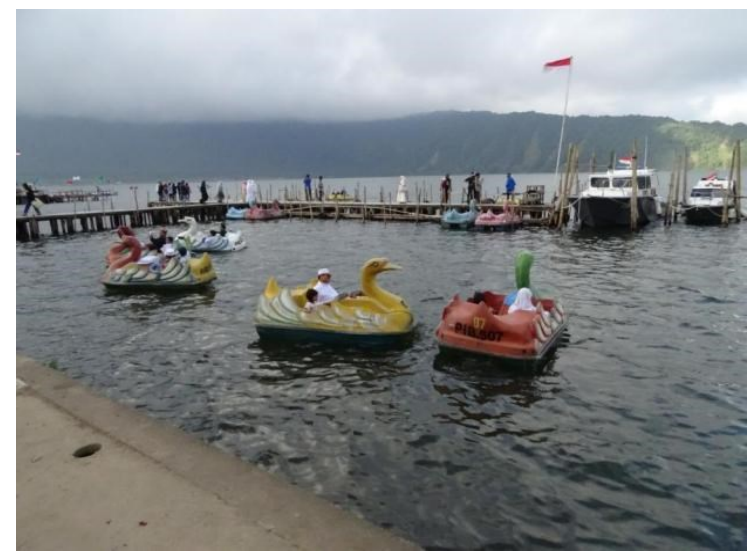

Figure 8. Tourist Attractions (Speed Boats and Banana Boats) (Speed boats and banana boats may generate a good income, but at the same time result in water pollution, i.e., fuel spills)

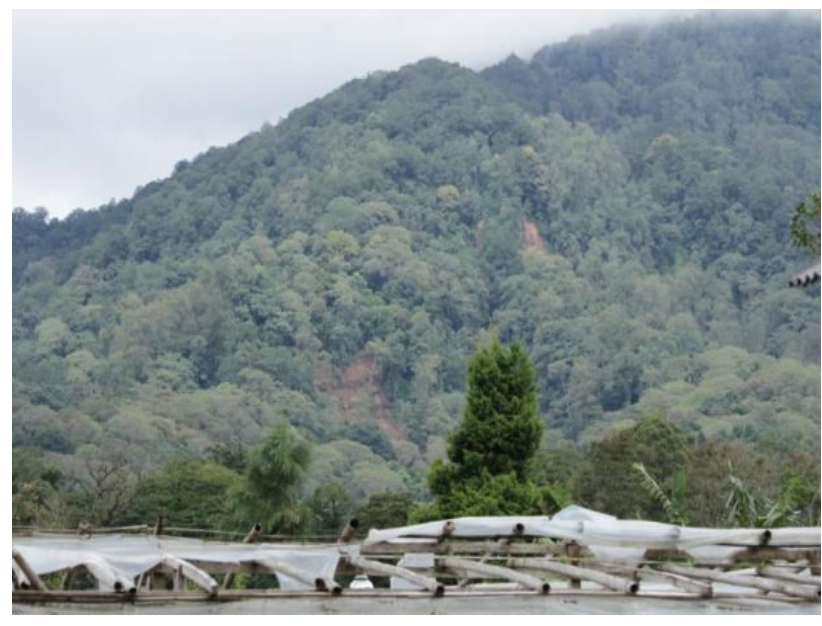

Figure 9. Landslides in 2017

(Landslides are a major risk in many parts of Bali, including Bedugul, during the rainy season)

\section{Conclusion}

There is a considerable concept to defining groups of people living in a location understand the ecosystems around them, and their relationship with the surrounding environment, and this study proved it. Bedugul landscape has a strong cultural and ecological relationships with its communities, both Hinduism and Islam. The socio-cultural conditions of the people of Bedugul, i.e., Hindus and Moslems, still hold firm religious traditions, including the "subak." The agricultural and tourism sectors are integral for Bedugul communities, as they are very dependent on both sectors. It has resulted in the lives of Bedugul people is developing economically, moving them closer to a middle-class status with more expendable income. However, land-use changes and the increasing population growth have resulted in the carrying capacity of the catchment area becoming very vulnerable. Some environmental problems and access to modern lifestyle have been 


\section{Bedugul Portrait: An Ethnoecological Study of the Relationship Between Man and the Environment}

identified, and this may result in the decline of local values within the Bedugul communities. This study concluded that erosion of traditional ecological knowledge, including ethnobotanical knowledge, is at risk of increasing. In today's modern era, cultural erosion is unavoidable. This study could fill the knowledge gap that the people of Bedugul might not realize that cultural erosion is happening among the communities. Cultural erosion might be mitigated with appropriate cultural programs. Also, continued use of the life philosophy of both communities is expected to conserve traditional ecological knowledge effectively.

\section{Acknowledgment}

The author would like to thank all the informants who provided information and their hospitality shown during the interview process. Information shared by informants is entirely to answer the purpose of this study, and there is no intention to commercialize it. This study was funded independently by the author.

\section{References}

As-syakur, A. R. (2007). Identifikasi hubungan fluktuasi nilai SOI terhadap curah hujan bulanan di Kawasan Batukaru - Bedugul, Bali. Jurnal Bumi Lestari, 72), 123-129. Retrieved from https://ojs.unud.ac.id/index.php/blje/article/view/2423.

Atmadja, A. T., Ariyani, L. P. S., \& Atmadja, N. B. (2016). Women as canang sari street vendors in Bali. Komunitas: International Journal of Indonesian Society and Culture, 8(1), 85-93. doi:10.15294/komunitas.v8i1.5116.

Atmaja, D. M., Budiastuti, M. S., Setyono, P., \& Sunarto, S. (2018). An ecohydrological-based management of Lake Beratan in Bedugul, Bali. IOP Conference Series: Earth and Environmental Science, 148, 1-8. doi:10.1088/1755-1315/148/1/012024.

Candrawan, I. B. G. (2015). Kosmologis masyarakat Hindu di Kawasan Tri Danu dalam pelestarian lingkungan hidup. Dharmasmrti, 13(26), 23-35.

Central Board of Statistics of Bali Province. (2017). Bali in Figures Year 2017. Denpasar: Central Board of Statistics of Bali Province.

Cukier-Snow, J., \& Wall, G. (1993). Tourism employment: Perspectives from Bali. Tourism Management, 14(3), 195-201. doi:10.1016/0261-5177(93)90020-L.

Inglis, J. T. (1993). Traditional ecological knowledge: Concepts and cases. Ottawa: International Development Research Centre.

Kvale, S. (1996). Interviews: An introduction to qualitative research interviewing. Thousand Oaks, CA: Sage Publications.

Nugroho, B. T. ., Undaharta, N. K. ., \& Siregar, M. (2008). Interaksi masyarakat sekitar hutan terhadap pemanfaatan keanekaragaman hayati di Kawasan Ekosistem Hutan Alami Bedugul-Pancasari, Bali. Biodiversitas, 9(3), 227-231.

Oktavia, G. A. E., Darma, I. D. P., \& Sujarwo, W. (2017). Studi etnobotani tumbuhan obat di Kawasan Sekitar Danau Buyan-Tamblingan, Bali. Buletin Kebun Raya, 20(1), 1-16.

Planck, U., \& Sutawan, N. (1983). Die sozialorganisation Balinesischer reisdörfer unter besonderer Berücksichtigung des Subak-Systems (The social organization of Balinese rice villages with special consideration of the Subak system). Erdkunde, 374), 282-292. doi:10.3112/erdkunde.1983.04.04.

Purnama, I. N., \& Ardyanti, A. A. A. P. (2017). Peramalan kunjungan wisatawan di obyek wisata Bedugul menggunakan algoritma fuzzy time series. Smartics, 3(2), 55-58. doi:10.21067/smartics.v3i2.2014.

Ratnasari, G. A. H. K., Siaka, I. M., \& Suastuti, N. G. A. M. D. A. (2013). Kandungan logam total Pb dan Cu pada sayuran dari sentra hortikultura daerah Bedugul. Jurnal Kimia, 72), 127-132. Retrieved from https://ojs.unud.ac.id/index.php/jchem/article/view/8222/6145.

Rema, N. (2013). Makna air bagi masyarakat Bali. Forum Arkeologi, 26(2), 109-124. 
Sujarwo, W., Arinasa, I. B. K., Salomone, F., Caneva, G., \& Fattorini, S. (2014). Cultural erosion of Balinese indigenous knowledge of food and nutraceutical plants. Economic Botany, 68(4), 426-437. doi:10.1007/s12231-014-9288-1.

Sujarwo, W., Keim, A. P., Savo, V., Guarrera, P. M., \& Caneva, G. (2015). Ethnobotanical study of Loloh: Traditional herbal drinks from Bali (Indonesia). Journal of Ethnopharmacology, 169, 34-48. doi:10.1016/j.jep.2015.03.079.

Sumantera, I. W. (2004). Potensi hutan Bukit Tapak sebagai sarana upacara adat, pendidikan, dan konservasi lingkungan. Biodiversitas, 5(2), 81-84.

Suradisastra, K., Sejati, W. K., Supriatna, Y., \& Hidayat, D. (2002). Institutional description of the Balinese subak. Jurnal Penelitian dan Pengembangan Pertanian, 21(2), 11-18.

Vickers, A. (1987). Hinduism and Islam in Indonesia: Bali and the Pasisir World. Ithaca: Southeast Asia Program Publications at Cornell University. doi:10.2307/3351220. 